\title{
The Changing Face of Crises and Aid in the Asia-Pacific
}

\author{
Elin A. Gursky, Frederick M. Burkle, Jr., David W. Hamon, Peter Walker, and Georges C. Benjamin
}

Both US foreign policy and global attention attest to the strategic, economic, and political importance of Asia. Yet, the region faces urgent challenges that must be addressed if it is to remain stable and prosperous. The densely populated countries of the Asia-Pacific are beleaguered by poverty, population displacement, decreasing access to potable water and adequate sanitation, and high rates of disease morbidity and mortality. New and reemerging diseases known to have originated in Asia over the past decades have spread globally by international trade, tourism, worker migration, and agricultural exportation. Unremitting naturally occurring and man-made disasters have strained Southeast Asia's already fragile disaster and public health response infrastructures and the essential services they provide (eg, surveillance, vaccination, maternal and child health, and mental health programs). Following disasters, governments often contract with the broader humanitarian community (eg, indigenous and international NGOs) and seek the assistance of militaries to provide essential services. Yet, their roles and capabilities in addressing acute and chronic health issues in the wake of complex disasters remain unclear. Current mechanisms of nation-state and outside organization interaction, including dissimilar operational platforms, may limit true partnership on behalf of the health security mission. Additionally, concerns regarding skill sets and the lack of standards-based training raise questions about the balance between developing internal response capabilities and professionalizing external, deployable resources. Both the mega-disasters that are forecast for the region and the global health security threats that are expected to emanate from them require an increased focus on improving the Asia-Pacific's emergency preparedness and response posture.

W Hen Typhoon Haiyan's 195-mph winds hit the central Philippines in November 2013, it followed more than 30 recorded deadly cyclones that have affected Southeast Asia. The Philippines and other countries of the region, referred to as the victims of "a confluence of meteorology, geography, population density, poverty and government,"1 benefited from a massive global postHaiyan humanitarian and recovery effort. This catastrophe illuminated the regional challenges associated with developing a robust emergency preparedness and response infrastructure, even in an area that has long acknowledged its vulnerability to natural disasters. Furthermore, Typhoon Haiyan helped galvanize the United States' and the world's growing concerns regarding the Asia-Pacific's importance to economic and political stability and its emerging global health security threats.

Elin A. Gursky, ScD, MSc, IDHA, is Distinguished Analyst and Corporate Fellow, ANSER/Analytic Services, Inc., Falls Church, Virginia. Frederick M. Burkle, Jr., MD, MPH, DTM, is Senior Fellow and Scientist, Harvard Humanitarian Initiative, Harvard University, Cambridge, Massachusetts, and Senior International Public Policy Scholar, Woodrow Wilson International Center for Scholars, Washington, DC. David W. Hamon is Director and Distinguished Analyst, Banyan Analytics/Analytic Services, Inc., Falls Church, VA. Peter Walker, PhD, is Dean, Falk School of Sustainability, Chatham University, Pittsburgh, Pennsylvania. Georges C. Benjamin, MD, is Executive Director, American Public Health Association, Washington, DC. 
For several years the United States has adopted an allhazards and "all-of-Nation" preparedness model, ${ }^{2}$ recognizing the finite response capabilities of any one government agency. Incorporating military assets into the civilian response effort has been posited as one strategy to improve surge capability and durability over the "response to recovery" postdisaster cycle. The disaster response role of the private sector has also been expanded in acknowledgment of its capabilities in logistics, product movement, and resupplying — and even in product distribution—one such model being medical countermeasure distribution by community pharmacies. ${ }^{3}$ As the United States explores efforts to refine health security capabilities and cross-sector collaboration, it is unclear to what extent these and other measures can be adapted for the Asia-Pacific preparedness and response effort. The unique resources and global health challenges of the Asia-Pacific, however, demand attention in addressing near-term threats and assembling resilient and anticipatory health infrastructures for long-term sustainable regional security.

This article reviews past and current threats to global health security and explores potential strategies for improving the Asia-Pacific's preparedness posture. As one example, we specifically address the potential role-and limitations - of the contributions of nongovernmental organizations (NGOs) to reducing population morbidity and mortality resulting from a pandemic or naturally occurring disaster.

\section{Significance of the Region FOR Global Stability}

Over the past 25 years, the Asia-Pacific has developed at a surprising rate, leading to a meteoric rise in its diplomatic, strategic, and economic importance. According to Lieutenant General Wallace Gregson (USMC, ret), former Assistant Secretary of Defense for Asian and Pacific Security Affairs, the region's sheer size, stretching from the Indian subcontinent to the western shores of the Americas, coupled with its demographic distinction as being home to over $60 \%$ of the world's population, ${ }^{4}$ makes it strategically important to America's future. ${ }^{5}$

The US government recognizes that the Asia-Pacific suffered neglect during the decade following 9/11, while China rose to become the second most powerful economy globally and the most important economy in Asia, overtaking Japan. This moved the United States to take deliberate steps to ensure that its interests are protected as the Asia-Pacific region continues to evolve. According to then-Secretary of State Hillary Clinton, "One of the most important tasks of American statecraft over the next decade will ... be to lock in a substantially increased investment-diplomatic, economic, strategic, and otherwise-in the Asia-Pacific region." ${ }^{\prime 6}$ The country's key priorities in the region include realigning its military posture; pursuing an ongoing campaign of nuclear deterrence; opening and expanding trade partnerships; promoting 2-way, foreign direct investment; and expanding security cooperation with partner nations. ${ }^{7}$

Early in his tenure, President Obama mandated that his national security team assess and strategically reprioritize America's foreign policy interests and provide a series of recommendations regarding areas requiring more US focus, resources, and presence. For better or worse, the Asia-Pacific is poised to shape the future global order in the decades ahead. ${ }^{7}$ According to an Asia Development Bank report, gross domestic product across Asia will continue to rise "as the recovery in the major industrial economies gains momentum," and "demand for Asia's output is expected to grow."

As Daniel R. Russel, Assistant Secretary of State for the Bureau of East Asian and Pacific Affairs, observed, "The effects of what happens in the Asia-Pacific Region will be felt across the globe and have direct implications for America's interests." 9

\section{Threats to Health Security}

Almost 600 million $^{10}$ people inhabit the countries of the Association of Southeast Asian Nations: Brunei, Cambodia, Indonesia, Laos, Malaysia, Myanmar, the Philippines, Singapore, Thailand, and Vietnam. ${ }^{11}$ Separated by diversity of cultures, religions, and political perspectives, the region is united by threats from climate; emerging and reemerging infectious diseases; accelerated rates of agricultural product exportation and its attendant risks from environmental degradation, food security problems, and worker migration; and a myriad of other vulnerabilities that have an impact on health, safety, and society. Inequities in nutrition and access to health care have negatively affected life expectancy and workforce productivity in some areas. Current and future conflicts fueled by competition over dwindling natural resources and access to potable water and adequate sanitation, along with urbanization and population dislocation, will strain regional stability and social and economic equality. Collectively these issues will present enormous challenges to governance. Increased energy demand, mounting nuclear issues (involving both weapons development and power generation), and transnational and nonstate terrorist movements threaten security and prosperity and contribute to instability, uncertainty regarding continued economic growth, and concern over the potential for future threats to broader US engagement in the region.

Extreme weather is familiar to Southeast Asia, especially the Philippines, which is located on a belt around the Pacific Ocean-the Ring of Fire-with frequent volcanic eruptions and earthquakes. ${ }^{12}$ According to Professor N. Vinod Chandra Menon, a global expert in emergency preparedness and disaster management, a UN disaster consultant, and author of the National Disaster Management Guidelines for India, from 1970 to 2010, the average number of people exposed to flooding in the Asia-Pacific 
more than doubled, from 29.5 million to 63.8 million. $^{13}$ Moreover, as disasters in Asia grow in complexity and severity, so does its economic burden. According to the UN regional adviser for disaster risk reduction, Sanjay Srivastava, both the global toll of natural disasters and its particular severity on the Asia-Pacific region were unprecedented: "Of the global U.S. $\$ 270$ billion of economic losses [attributed] to natural disasters in $2011,90 \%$ was in Asia." 14

The 2011 Japanese triple disaster-earthquake, tsunami, and nuclear meltdown-was a unique cascading event, a natural disaster turned technical or man-made disaster. More than 15,800 people in the region died, and 340,000 were displaced. ${ }^{15}$ Although there was no discernible illness in those exposed to radiation, the displaced will require continual, probably lifelong, health monitoring. The world was not prepared for this event, and the international response and integration with the Japanese authorities fell short. $^{16}$

Predictive modeling suggests that Southeast Asia will continue to be disproportionately affected by severe climate events. The report "Climate Change 2014: Impacts, Adaptation, and Vulnerability"17 offers sobering concerns, particularly regarding populations in the coastal regions of Asia. Climate change may cause the rise of annual mean temperature by 4.8 degrees centigrade by 2100 compared to $1990 .{ }^{18}$ "Hundreds of millions of people are likely to lose their homes as flooding, famine and rising sea levels sweep the region." 19 Sea-level rise and storm surge are predicted to affect cities that include Bangkok, Jakarta, Yangon, Manila, and Ho Chi Minh City. ${ }^{20}$ The displacement of communities of small farmers and fishermen in rural and low-lying coastal areas will contribute to Southeast Asia's already high levels of poverty. Data from 2005 indicate that $18.8 \%$ (93 million) of the region's population lived below the $\$ 1.25$-a-day poverty line, and 44\% (221 million) lived below the $\$ 2.00$-a-day poverty line. ${ }^{18}$

The list of problems associated with the effects of changing climate is broad and includes coastal flooding; land loss, diminished crop yields, and dislocation of crop cycles; erosion of the food supply; extreme precipitation; and flooding as well as drought and water scarcity. Increased urbanization will lead to higher population density, competition over resources, and increased transmission of communicable diseases. ${ }^{18}$

Unremitting destructive forces of nature have an impact on populations already burdened by high levels of poverty, acute and chronic disease, and limited health and disaster response infrastructures. Threats to regional and global populations from emerging and reemerging diseases in Asia, the result of "complex, dynamic systems in which biological, social, ecological, and technological processes interconnect," 10 have been universally recognized as a major concern by the health, political, and business sectors. The Asian Development Bank has clearly articulated the effects of climate on health and the economy: increasing morbidity and mortality associated with thermal stress (the effects of heat and cold); vectorborne diseases such as malaria, cholera, and dengue; and waterborne diarrheal diseases (eg, amoebiasis, giardia, typhoid fever, and shigellosis) from contaminated groundwater. ${ }^{10}$

Although Southeast Asia has historically been known as a hotspot for newly evolving diseases, many of the world's decision makers have been critically slow in recognizing the increasing impact the region has in the proliferation of infectious disease via robust international business travel, tourism, foreign worker exchange, migrant workers, and the exportation of food and agricultural products. ${ }^{21} \mathrm{New}$ and reemerging diseases that have arisen over the past decades have spread by the increasing density of populations and unregulated animal markets. ${ }^{10}$ Both direct and indirect links are attributable to water scarcity in at least two-thirds of China's cities. A survey by the Ministry of Land and Resources shows that the "North China Plain suffers from severe groundwater pollution with over $70 \%$ of overall groundwater quality classified as Grade IV+, in other words, unfit for human touch." 22 "Life expectancy in the north has decreased by 5.5 years due to air pollution, and severe water contamination and scarcity have compounded land deterioration." 23 Over the past 20 years, China has lost 28,000 of its rivers $(54 \%)$ as a result of rapid development; increased industrial, agricultural, and household consumption; and lack of management controls. ${ }^{24}$ The massive use of pesticides, fertilizers from agricultural runoff, industrial chemicals, and human and animal waste have altered the downstream microorganism ecology, resulting in "rivers and lakes throughout China blighted by algae blooms caused by fertilizer run-off, bubbling chemical spills and untreated sewage discharges" that end up along the South China Sea coastline. ${ }^{25}$ This has led to an unprecedented, complex, and burgeoning pool of new and resistant microorganisms, a public health risk that is impossible to reverse.

The emerging infectious diseases emanating from the Asia-Pacific region include avian influenza $\mathrm{A} / \mathrm{H} 5 \mathrm{~N} 1$, severe acute respiratory syndrome (SARS), and Nipah virus. Southeast Asia bore witness to the emergence of Vibrio cholera $01 \mathrm{El}$ Tor and the first major outbreaks of hemorrhagic dengue. Reemerging diseases include chikungunya, Japanese encephalitis, and leptospirosis. Both multipledrug-resistant and extensively drug-resistant tuberculosis pose large global public health concerns. ${ }^{10}$ Artemisininresistant Plasmodium falciparum threatens the gains accrued in reducing the number of diagnosed malaria cases by $43 \%$ and deaths by $68 \%$ from 2003 to $2011 .{ }^{26} \mathrm{New}$, potentially lethal strains of H7N9 avian flu have been detected in China, silently spreading in poultry and causing at least 200 human cases and 100 deaths, all from live-bird markets. Lack of robust public health systems has led the vaccination rates for children to plummet $15 \%$ in China within a few months, making more than 500,000 children susceptible to diseases such as measles. 


\section{The Role of NGOs}

Responsibility for the conditions described above and their negative impact on the health of populations historically has fallen to the governmental public health sector, the spectrum of agencies spanning state health ministries to local offices. Inextricably linked to issues of security and prosperity, poor public health can infringe upon a nation's ability to defend and provide for itself, causing it to rely on benefactor nations for assistance while leaving it vulnerable to aggression from predatory states and nonstate actors. Additionally, public health can be severely affected by disruptions to security and the economy. The extreme weather events and a spectrum of regional instability and health security threats in the Asia-Pacific described earlier reinforce the importance of preventing epidemics, detecting biological threats, and rapidly responding to disease outbreaks. ${ }^{27}$ Effective postdisaster public health response is crucial not only for saving lives, but also for preventing a downward spiral that could leave an area economically weak and politically vulnerable.

Indigenous government agencies (often already strained) may be required to request additional external assistance in situations of duress. To help accomplish a specific mission and augment government's role, NGOs, including international NGOs, can be contracted by governments or through the donor community.

NGOs are private institutions, operating under the legal definitions of their countries of origin, but without benefit of formal international certification or a system of accreditation. In most crises NGOs are coordinated in their work by the UN's Office for the Coordination of Humanitarian
Affairs. Both indigenous and international NGOs serve increasingly important roles in the acute and post-acute development phases following disasters and in extending the public health mission.

Latest figures suggest that about $70 \%$ of international humanitarian aid flowing through NGOs is funded by rich governments that are members of the Organization for Economic Co-operation and Development in the northern hemisphere; their NGOs are often referred to as "Northern NGOs." Almost all the rest comes from private and foundation donations. Governments outside the organization contribute less than $5 \%$ of the global funding. ${ }^{28}$

The international humanitarian response system has grown rapidly over the past few years and now regularly spends more than $\$ 15$ billion annually. It assists 100 million to 150 million people a year and employs about 210,000 workers. ${ }^{29}$ But these statistics are deceptive. The system is dominated by a few big players: 12 to 40 international NGOs, $4 \mathrm{UN}$ agencies, and the Red Cross and Red Crescent. The vast majority of their spending is in Africa and the Middle East, with 70\% going into operations that have been going on for at least 5 years. The international humanitarian aid system is designed to respond to big wars, refugees, or famine ${ }^{28}$ (Figure 1).

While the NGO communities of practice differ worldwide, there is an ongoing debate about the role of NGOs in Asia-Pacific countries and whether the contemporary roles of NGOs fostered in Africa are compatible. The debate focuses on issues of both competency and context.

Most humanitarian responses take place in countries that cannot or will not put in place effective preparedness and

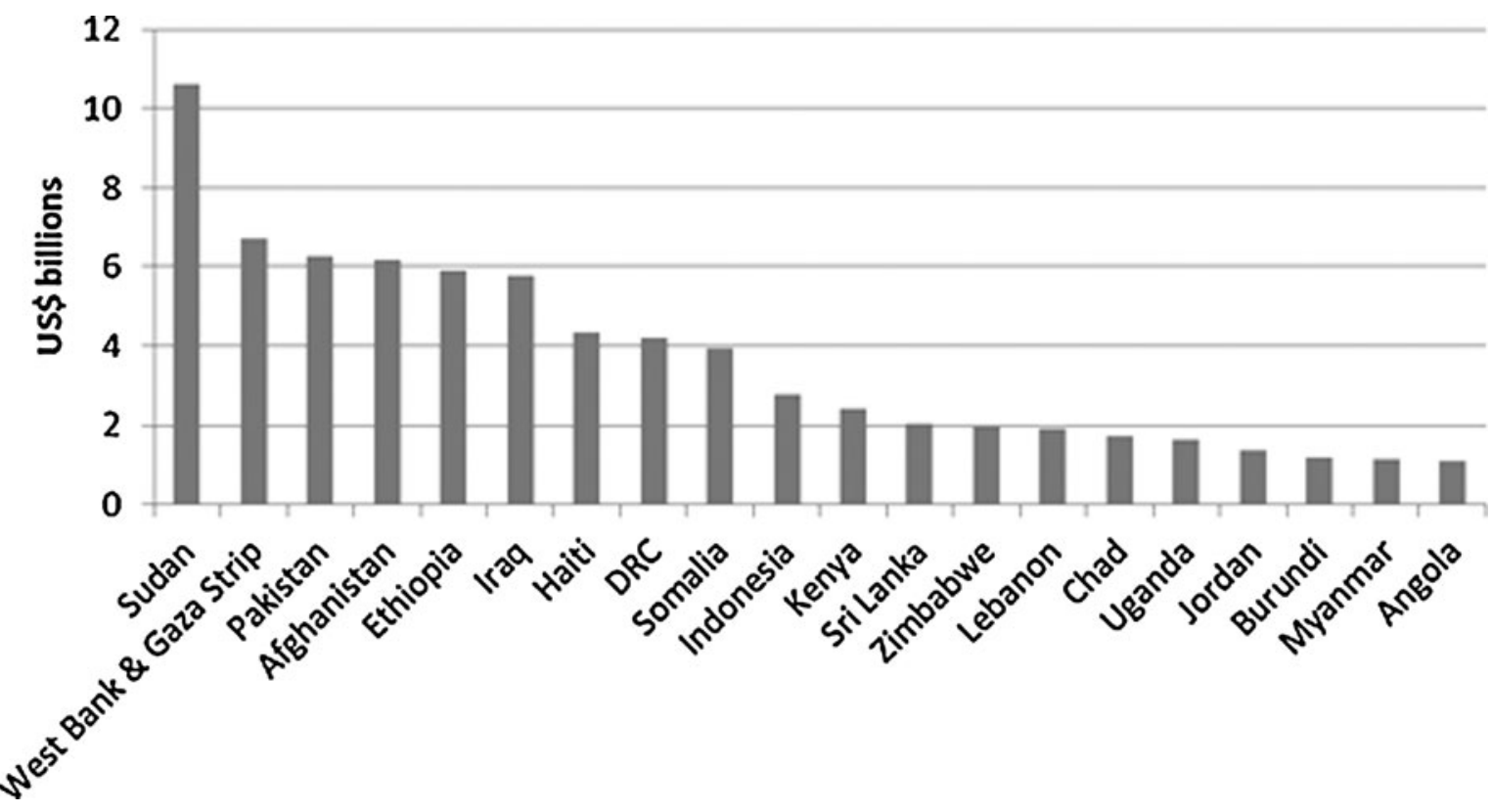

Figure 1. Of the top 10 recipients of humanitarian cash transfer programs from 2008 through 2012, only 2 countries were in the Asia-Pacific region, based on data from the UN Office for the Coordination of Humanitarian Affairs Financial Tracking Service. 
response mechanisms and where affected populations need to rely on outside assistance. Almost all of this assistance is provided through NGOs, some of them turning over more than $\$ 3$ billion a year. NGOs come out of a tradition of charitable, voluntary action; until very recently, this also meant a tradition of doing what they could, rather than what they should. In the 1990s, agreed upon crisis standards for minimal assistance were developed and defined for the vital areas of food, water, sanitation, shelter, and health access. These standards constitute an essential public health infrastructure and have been continuously updated not only to provide benchmark standards, but also to serve as key indicators for best practices. ${ }^{30}$

Within context, global organizations tend to create global standards and global ways of delivering aid; yet everything we know about making interventions work in crises tells us that local responses have to be nuanced to the local context, whether in banking, food, or health. International agencies have historically been remarkably poor at this. Of the $\$ 15$ billion yearly that goes into humanitarian assistance, less than $5 \%$ goes directly to local organizations. It is preferred that outside NGOs partner with local NGOs and organizations, looking to the local organizations to provide contextual knowledge and experts who understand the culture and local systems, the laws, and access to the affected communities. Unfortunately, all too often what happens is that local organizations are subcontracted to deliver externally designed aid.

There are 4 major reasons that these existing traditional international NGO models do not work well when applied to the Asia-Pacific:

1. The current international NGO system is interventional, assuming that local capacities and resources are minimal. On the contrary, the education levels and entrepreneurial drive in Asia are quite strong. This interventionist approach sees partnership more as a delivery conduit for outside products than a truly equitable arrangement to get the best out of both systems.

2. The western NGO system is weary of working through the state, seeing it as part of the problem, not part of the solution. Yet, in Asia the state is a far stronger institution than in Africa, with a much longer history and greater dependability. State structures are a vital part of the future, particularly in public health, where working with the state to strengthen the structures is vital, particularly in urban areas.

3. Western NGOs are cautious about working with the military, often seeing this as a direct contravention of their notions of neutrality, derived from the Geneva Conventions. But in Asia the armed forces are a vital and central part of disaster response.

4. Western NGOs are rural, not urban, in focus, yet the future of Asia is urban. The continent is urbanizing at a rapid rate, but public health infrastructure and approaches are not keeping pace. Even the basic commitments to supply potable water, safe and sustainable disposal of waste, and control of air, water, and soil pollution are not in place, let alone disease surveillance and public health prevention strategies. There is little or no international NGO presence in the sprawling cities of Asia. While many still believe that the highest mortality rates exist in rural Africa, there is grave concern that the highest mortality rates for infants, children under age 5 , and mothers are in urban Asia. Traditional western-based NGOs do not have relief plans for these urban settings. Where the industry standards for aid levels promoted by the Sphere Project ${ }^{20}$ are strictly used for refugee camps, even minimal standards for safe living have not been met in dense urban settings. ${ }^{31}$

\section{Enhancing and Professionalizing Disaster Response}

As the broader humanitarian enterprise has grown in size and complexity over the past 3 decades, calls have come for better scrutiny, accountability, and transparency for both beneficiaries and donors and for the establishment of a formal profession of humanitarian aid. Unfortunately, "the demand for better coordination and control is heard during and after every major large-scale international disaster,"32 bringing newfound attention to the professionalization process as one potential framework to address this issue.

Education efforts in North America, the United Kingdom, the European Union, and Australia have been initiated from both academic and nation-state resources, but on a limited basis. Research and peer-reviewed publications on competency-based curriculum development and outcome studies have been robust, but the movement has lacked proper funding, legislation, and collective interest, especially from NGOs that generally prefer in-house training and evaluation. Core competencies across the humanitarian sector are being defined, and universities are beginning to offer training and education that speak directly to those competencies. However, a 2013 review of research on the humanitarian sector's health interventions showed that surprisingly few practices are actually evidence based. ${ }^{33}$

Interest in this process remains high, nonetheless, among health-related NGOs because they recognize that additional competencies are required above those of their licensed skills in their own countries. Education and training for healthrelated providers generally focus on adjusting and adapting health skills to resource-poor or resource-constrained settings and to requirements for working in concert with international humanitarian law and international organizations such as the World Health Organization (WHO) Health Cluster and Office for the Coordination of Humanitarian Affairs. While there has been little or no interest in 
organized professionalization from crisis-prone Asian countries, many indigenous aid organizations have kept to high standards in deployed teams, especially foreign medical teams from Japan, New Zealand, and Australia. Classification and minimum standards for foreign medical teams in sudden-onset disasters were published in 2013 under the auspices of WHO. Until recently, notions of professionalism were lacking. This is beginning to change, with the medical NGOs leading the way, undoubtedly because they draw on medical professionals for the majority of their technical and senior staff.

\section{Improving the Asia-Pacific's Global Health Infrastructure}

An effective public health response throughout the entire disaster cycle will not be realized without robust professionalization and a globally harmonized education process across all aid and assistance organizations-government and nongovernment-especially where broad coordination, resource allocation, and evidenced-based outcome data documentation are crucial to success. This is especially true in nation-states where indigenous government public health capacity and disaster preparedness competencies are still evolving. The need and potential for NGO growth in the Asia-Pacific is strong, but the common thread of multidisciplinary complex public health emergencies demands that professionalization be introduced early, especially in health-related crises such as Typhoon Haiyan, in which foreign medical teams were welcome but not equal in their capabilities.

Other regional and international initiatives can improve disaster response and global health security from threats emanating from the Asia-Pacific. These initiatives will not only benefit a rapidly shrinking world, but will improve health indicators and economic and political stability for the population of this region.

- The US Department of State is pursuing a 6-strand strategy designed to direct increased efforts and resources to the Asia-Pacific. Commonly known as the "rebalance toward Asia," this involves implementing a comprehensive, multidimensional strategy: strengthening alliances; deepening partnerships with emerging powers; building a stable, productive, and constructive relationship with China; empowering regional institutions; and helping to build a regional economic architecture that can sustain shared prosperity. ${ }^{7}$ Each of these strands holds the potential to support health and emergency response infrastructures, directly and indirectly.

- Asia has many problems of disaster risk: poor regulatory oversight of industry (especially industries that produce chemicals or other hazardous materials), unenforced building and construction codes, lack of a safety culture, lack of disciplined incident response and management systems, poor resources for emergency preparedness, lack of experience in nuclear power generation, and much more. To address this spectrum of issues that affect health, the environment, and economies, the Hyogo Framework for Action was undertaken in an ambitious effort to improve the integration of disaster reduction into sustainable development policies and planning; development and strengthening of institutions, mechanisms, and capabilities to build resilience to hazards; and the systematic incorporation of risk reduction approaches into the implementation of emergency preparedness, response, and recovery programs. ${ }^{34}$ This includes a UN strategy for developing a Pacific regional disaster risk reduction framework to prevent or mitigate threats to the public's health and acknowledges that, with excess population numbers and density, many of China's cities already function, with all the public health implications, as chronic "mass gatherings."

- WHO's mandate for pandemics under the International Health Regulations (IHR) treaty represents the opening of a door for wider global cooperation, echoed by a call in The Lancet for a collective manifesto for planetary health. ${ }^{35}$ This movement begets a larger question for the broad humanitarian community and capacity for national and international NGOs to guarantee the coordination of a powerful social movement based on collective action at every level of society. This issue was raised after the debacles in Haiti and Pakistan, which again revealed that before, during, and after every major crisis there was a demand for better coordination and control. The authors referred to the IHR as a potential framework to meet this demand. A global authority, required for all large-scale disasters and crises, does not exist. ${ }^{36}$ However, such a collective action would require nothing short of a treaty-level global authority for prevention and preparedness, one that embodies and operationalizes the empirical work of the former Intergovernmental Panel on Climate Change and other scientists who have the technical expertise and institutional basis to devise the treaty content and implementation. ${ }^{37}$ Along with an international authority needed to guarantee a stable and strategic return to root-cause remediation and development is the need to professionalize all responders under a set of core competencies and a centrally held registry of those certified by such education and training. More than 14 academically affiliated training centers exist in North America alone, with emerging partnerships in the UK, the European Union, East Africa, and Australia. ${ }^{29,38}$

- Crisis and disaster risk reduction begins and ends at the local level. This concept recognizes that individual communities are both unique and discrete in better understanding what individual risks they live with and what the impact would be of any disaster on both their 
communities and their needs. Letting the community anticipate and assess local characteristics and risks has revealed that considerable information was not known through traditional top-down assessments. Planning and response efforts must incorporate civil input to improve effectiveness and efficiency. This concept must be adapted to every culture but is most appropriate to the historically rich and stable communities in the Asia-Pacific that have developed resilience capacities over centuries. ${ }^{29,39}$

- The IHR became a treaty in 2007. While 196 countries have signed it, requiring them to report outbreaks promptly to WHO and take country-wide responsibility to control them, the majority of countries have not fully complied. The treaty has not met its full potential, and revisions are necessary to ensure global health security. This is a responsibility of all nations, but in reality the developed countries of the region and the newly invigorated Association of Southeast Asian Nations must play increasingly pivotal roles. While technologies for economic gain are transferred and even copied at ease across borders, the import of public health infrastructure linked to social protection programs as an essential commodity (as it has been for centuries in Europe and elsewhere) has not been a national priority nor understood as anything more than a nation-state nuisance. $\mathrm{WHO}$ and its member states, all signatories to the treaty, are considering expanding the scope of required disease reporting to include all public health emergencies of international concern and devising a system for better cooperation with WHO and other countries.

\section{Final Thoughts}

While it is easy to become preoccupied with the global health consequences of disasters like those of Typhoon Haiyan, crises affecting the health of nations will not be solved by any one discipline — certainly not medicine or public health alone-or by any one nation-state. Many global health initiatives that dominate world powers' foreign policy agendas-for example, US and Chinese short-term deployments of hospital ships to developing countries - are highly competitive, government-centric, and limited in providing substantive outcomes. Preventive solutions emphasizing preparedness will arise from multi- and transdisciplinary collaborations among the social sciences, humanities, natural sciences, political sciences, economics, law, diplomacy, health and public health sectors, and civil engineering, to name but a few disciplines. Many traditionally grounded professionals remain averse to accelerating solutions outside their favored discipline. Worse still, political decision makers rarely see the benefits of science and are reluctant to engage in discourse with scientists. It remains ironic that scientific advances for the sake of economic dominance are actually accelerating the destruction of public health, global health security, and the environment.
With modern-day large-scale disasters such as the 2003 SARS pandemic, the 2004 Indian Ocean tsunami, and 2013 Typhoon Haiyan, the broad disaster relief and humanitarian community has focused primarily on response, with little attention or resources devoted to prevention and preparedness. But like responses to major disasters in the past, these responses have suffered from poor oversight, coordination, and accountability; lack of professionalism; and corruption - particularly in urban areas. Countries are not prepared to handle emergencies of scarcity-primarily of food, water, and energy - that have a grave impact on import-dependent countries such as China, Japan, and South Korea and competitively increase risks for conflict over fishing and petroleum rights in the South China Sea. What added destruction will arise from climate events and emerging infectious diseases remains undefined. With the relative certainty of future disaster megatrends, the public health infrastructure, already severely compromised, risks further massive decline. Without a political commitment to shared regional and global ownership, productive gains will be limited in the Asia-Pacific with each and every crisis.

\section{REFERENCES}

1. Mersereau D. Why so many people died from Haiyan and past Southeast Asia typhoons. Washington Post November 11, 2013.

2. Presidential Policy Directive/PPD-8: National Preparedness. US Department of Homeland Security website. March 30, 2011. http://www.dhs.gov/presidential-policy-directive-8national-preparedness. Accessed September 8, 2014.

3. US Department of Health \& Human Services, Office of the Assistant Secretary for Preparedness \& Response, Division of Medical Countermeasure Strategy \& Requirements. Public Input on Medical Countermeasures: Seattle \& King County. Executive Summary. November 2011. https://www.phe.gov/ Preparedness/mcm/Documents/Seattle-Engagement-ExecutiveSummary.pdf. Accessed September 8, 2014.

4. Statistical Yearbook for Asia and the Pacific 2012. United Nations Economic and Social Commission for Asia and the Pacific. www.unescap.org/stat/data/syb2012/did-you-know.asp. Accessed September 8, 2014.

5. Gregson W. An imperative for clarity in U.S. foreign policy toward the Asia-Pacific. Banyan Analytics BriefSeptember 4, 2013.

6. Clinton H. America's Pacific century. Foreign Policy October 11, 2011

7. Donilon T. The United States and the Asia-Pacific in 2013. Asia Society; New York City; March 11, 2013.

8. ADB sees steady growth for developing Asia. Asian Development Bank April 1, 2014.

9. Russel DR. Hearing: America's future in Asia: from rebalancing to managing sovereignty disputes. Subcommittee on Asia and the Pacific of the House Committee on Foreign Affairs, 113th Congress, 2nd Sess. February 5, 2014.

10. Coker RJ, Hunter BM, Rudge JW, Liverani M, Hanvoravongchai P. Emerging infectious disease in southeast Asia: regional challenges to control. Lancet 2011 Feb 12;377(9765): 599-609. 
11. Hirschman C, Bonaparte S. Population and society in Southeast Asia: a historical perspective. In: Williams L, Guest MP, eds. Demographic Change in Southeast Asia: Recent Histories and Future Directions. Ithaca, NY: Southeast Asia Program Publications, Cornell University; 2012.

12. Wingard J, Brandlin A. Philippines: a country prone to natural disasters. Deutsche Welle November 10, 2013.

13. Menon NVC. Mechanisms for integrated response to mega disasters in the Asia-Pacific. Presentation at Analytic Services, Falls Church, VA; April 17, 2014.

14. Flood deaths down but economic losses significant. United Nations Office for Disaster Risk Reduction website. December 11, 2012. http://www.unisdr.org/archive/30026rence. Accessed September 8, 2014.

15. Hobson C. Human security in Japan after the 11 March disasters. United Nations University March 29, 2012.

16. Casto C. Lessons learned from Fukushima. Presented at International CBRNe response: identifying challenges to delivering capabilities in the Asia-Pacific conference. Washington, DC; April 2014.

17. Climate change 2014: impacts, adaptation, and vulnerabilitysummary for policymakers. Intergovernmental Panel on Climate Change, Working Group II, Fifth Assessment Report. March 31, 2014.

18. Asian Development Bank. The Economics of Climate Change in Southeast Asia: A Regional Review. Manila: ADB Publishing; 2009.

19. McKie R. Global warming to hit Asia hardest, warns new report on climate change. London Observer March 22, 2014.

20. Ponnudarai P. Climate change conjures up "alarming" scenarios in Southeast Asia. Radio Free Asia July 2, 2013.

21. Acuin J, Firestone R, Htay T, et al. Southeast Asia: an emerging focus for global health. Lancet 2011 Feb 12;377(9765):534535.

22. China Water Risk. Resources: analysis \& reviews. Hong Kong. China Water Risk website. North China Plain groundwater: $>70 \%$ unfit for human touch. February 26, 2013. http:// chinawaterrisk.org/notices/north-china-plain-groundwater70-unfit-for-human-touch/\#sthash.ORz5Ff5l.dpuf. Accessed September 8, 2014.

23. Xu B. China's environmental crisis. Council on Foreign Relations website. April 25, 2014. http://www.cfr.org/china/ chinas-environmental-crisis/p12608. Accessed September 8, 2014.

24. Hsu A, Miao W. 28,000 rivers disappeared in China: what happened? Yale Center for Environmental Law \& Policy website. June 2013. http://envirocenter.yale.edu/uploads/ Newsletters/[June\%202013\%20Newsletter] \%2028,000\% 20Rivers\%20Disappeared\%20in\%20China:\%20What\%20 Happened.pdf. Accessed September 8, 2014.

25. Stanway D. After China's multimillion-dollar cleanup, water still unfit to drink. Reuters February 20, 2013. http://www. reuters.com/article/2013/02/20/us-china-pollution-wateridUSBRE91J19N20130220. Accessed September 8, 2014.

26. Drug-resistant malaria gaining ground in SE Asia. Asian Scientist Magazine March 5, 2014.

27. The global health security agenda and what it means for the Asia-Pacific. Banyan Analytics Brief February 19, 2014.

28. Buston O, Smith K. Global Humanitarian Assistance Report 2013. Bristol, UK: Global Humanitarian Assistance; 2013. http://www.globalhumanitarianassistance.org/wp-content/ uploads/2013/07/GHA-Report-2013.pdf. Accessed September 8, 2014.

29. Walker P, Hein K, Russ C, Bertleff G, Caspersz D. A blueprint for professionalizing humanitarian assistance. Health Aff (Millwood) 2010;29(12):2223-2230.

30. Sphere handbook: Humanitarian charter and minimum standards in humanitarian response. Sphere Project website. 2011. http://www.spherehandbook.org/. Accessed September 8, 2014.

31. Urbanization and Humanitarian Access Working Groups, Rouhani SA, Patel RB, Janneck LM, Prasad A, Lapitan J, Burkle FM. Urbanization and Humanitarian Access Working Group: A blueprint for the development of prevention and preparedness indicators for urban humanitarian crises. Prehosp Disaster Med 2011 Dec;26(6):460-463.

32. Burkle FM Jr, Lyznicki JM, James JJ. Cross-disciplinary competency and professionalization in disaster medicine and public health. In: Gursky E, Hrečkovski B, eds. NATO Handbook for Pandemic and Mass-Casualty Planning and Response. Amsterdam, Netherlands: IOS Press; 2012.

33. Blanchet K, Sistenich V, Ramesh A, et al. An Evidence Review of Research on Health Interventions in Humanitarian Crises. London: London School of Hygiene and Tropical Medicine; 2013. http://reliefweb.int/sites/reliefweb.int/files/ resources/Evidence\%20Review\%20R2HC\%20Full\%20Report \%20FINAL_2.pdf. Accessed September 8, 2014.

34. Burkle FM Jr, Egawa S, MacIntyre AG, Otomo Y, Beadling CW, Walsh JT. The 2015 Hyogo Framework for Action: cautious optimism. Disaster Med Public Health Prep 2014 Jun;8(3):191-192.

35. Horton R, Beaglehole R, Bonita R, Raeburn J, McKee M, Wall S. From public to planetary health: a manifesto. Lancet 2014 Mar 8;383(9920):847.

36. Burkle FM Jr, Redmond AD, McArdle DF. An authority for crisis coordination and accountability. Lancet 2012 Jun 16;379(9833):2223-2225.

37. Burkle FM Jr. A manifesto for planetary health. Lancet 2014 Apr 26;383(9927):1459.

38. Burkle FM Jr. The development of multidisciplinary core competencies: the first step in the professionalization of disaster medicine and public health preparedness on a global scale. Disaster Med Public Health Prep 2012;6(10):10-12.

39. Rogers P. Development of a resilient Australia: enhancing the PPRR approach with anticipation, assessment and registration of risks. Australian Journal of Emergency Management 2011;26(1):54-58.

Manuscript received May 2, 2014;

accepted for publication August 2, 2014.

Address correspondence to: Elin A. Gursky, ScD, MSc, IDHA Distinguished Analyst \& Corporate Fellow ANSER/Analytic Services, Inc. Falls Church, $V A$

Email: Elin.Gursky@anser.org 